\section{Evaluation of the Cases who Applied to University Hospital Child and Adolescent Mental Health Committee Because of Sexual Abuse}

\author{
Bir Üniversite Hastanesi Çocuk ve Ergen Ruh Sağlığı \\ Adli Kuruluna Cinsel Istismar Nedeniyle Başvuran \\ Olguların Değerlendirilmesi
}

\section{Birsen Şentürk Pilan $\odot$ Serpil Erermiş $\odot$ Tuğçe Özcan $\odot$ Reyhan Çalışan $\odot$ illayda Barankoğlu $\odot$ Ahsen Kaya $\odot$ Ender Şenol $\odot$ Hülya Güler $\odot$ Ahmet Acarer $\odot$ Tezan Bildik $\odot$}

\section{ABSTRACT}

Objective: The aim of this study was to examine the sociodemographic characteristics, psychiatric diagnoses and factors associated with psychiatric diagnoses of children and adolescents who are victims of sexual abuse.

Method: The files of 92 children and adolescents aged between 0-18 who were referred to University Hospital Child and Adolescent Psychiatry Forensic Policlinic between January 2017 and December 2019 due to sexual abuse were evaluated retrospectively. Psychiatric diagnoses of the cases were made according to DSM 5 diagnostic criteria. Intellectual capacity of the cases was evaluated according to the latest verison of Wechsler Intelligence Scale for Children.

Results: In our study, 78 (84.8\%) cases were female and 14 (15.2\%) were male. Mean age of the cases was $14.1 \pm 3.88$ years. The most common type of sexual abuse was touching $(52.2 \%, n=48)$. There was a psychiatric diagnose in 50 (54.3\%) of them. The most common psychiatric diagnoses were posttraumatic stress disorder $(n=29,31.5 \%)$ and major depressive disorder $(n=25,27.2 \%)$. The rate of psychiatric diagnosis was significantly higher in cases exposed to coercion and violence ( $p=0.032)$. In 32 cases $(34.8 \%)$, it was determined that the abuser was within the family.

Conclusion: Sexual abuse has an effect on child's development throughout life.In our study, the rate of psychiatric diagnosis was high. It is very important to provide the necessary psychiatric support to the victims of sexual abuse. With the studies to be done in this area, awareness can be increased and necessary precautions can be taken.

Keywords: Sexual abuse, child and adolescent, mental health

\section{öz}

Amaç: Bu çalışmanın amacı cinsel istismar mağduru çocuk ve ergenlerin sosyodemografik özelliklerini, psikiyatrik tanılarını ve psikiyatrik tanılarla ilişkili faktörleri incelemektir

Yöntem: Ocak 2017-Aralık 2019 tarihleri arasında Üniversite Hastanesi Çocuk ve Ergen Psikiyatrisi Adli Polikliniğine cinsel istismar nedeniyle başvuran 0-18 yaş arası 92 çocuk ve ergenin dosyaları geriye dönük olarak değerlendirildi. Olguların psikiyatrik tanıları DSM 5 tanı ölçütlerine göre konuldu. Olguların zihinsel kapasiteleri, Wechsler Çocuklar İ̧̧in Zeka Ölçeği'nin (Wechsler Intelligence Scale for Children) son sürümüne göre değerlendirildi.

Bulgular: Çalışmamızda olguların 78'i $(\% 84,8)$ kız, 14'ü $(\% 15,2)$ erkekti. Olguların yaş ortalaması $14.1 \pm 3.88$ yıl idi. En sık görülen cinsel istismar türü dokunma idi $(\% 52,2, n=48)$. Bunların 50'sinde $(\% 54,3)$ psikiyatrik tanı vardı. En yaygın psikiyatrik tanılar post travmatik stres bozukluğu $(n=29, \% 31,5)$ ve majör depresif bozukluk $(n=25, \% 27,2)$ idi. Zorlama ve şiddete maruz kalan olgularda psikiyatrik tanı oranı anlamlı olarak daha yüksekti $(p=0,032)$. Otuz iki olguda $(\% 34,8)$ istismarcının aile bireyi olduğu belirlendi.

Sonuç: Cinsel istismarın çocuğun gelişimi üzerinde yașam boyu etkisi vardır. Çalışmamızda psikiyatrik tanı oranı yüksek bulunmuştur. Cinsel istismar mağdurlarına gerekli psikiyatrik desteğin sağlanması çok önemlidir. Bu alanda yapılacak çalışmalar ile farkındalık arttırılabilir ve gerekli önlemler alınabilir.

Anahtar kelimeler: Cinsel istismar, çocuk ve ergen, ruh sağlığı
Received: 11.08 .2020

Accepted: 18.01 .2021

Published Online: 03.08 .2021

Cite as: Sentürk Pilan B, Erermiş S, Özcan T, et al. Evaluation of the cases who applied to university hospital child and adolescent mental health committee because of sexual abuse. Izmir Dr. Behçet Uz Çocuk Hast. Dergisi. 2021;11(2):123-32.

Birsen Şentürk Pilan Ege Üniversitesi Çocuk ve Ergen Ruh Sağlığı ve Hastalıkları Anabilim Dalı İzmir, Türkiye

drbirsensenturk@yahoo.com ORCID: 0000-0002-4580-7655

S. Erermiş 0000-0001-6242-7876

T. Özcan 0000-0001-9520-3246

R. Çalışan 0000-0002-3453-2940

i. Barankoğlu 0000-0002-9340-499X

T. Bildik 0000-0002-0032-7025

Ege Üniversitesi Çocuk ve

Ergen Ruh Sağlığı ve Hastalıkları Anabilim Dalı, Izmir, Türkiye

A. Kaya 0000-0002-6969-1562 E. Şenol 0000-0001-9018-2466

H. Güler 0000-0002-3205-4113 Ege Üniversitesi Adli Tıp Anabilim Dalı, Izmir, Türkiye

A. Acarer 0000-0003-1194-3971 Ege Üniversitesi Nöroloji Anabilim Dalı, Izmir, Türkiye 


\section{INTRODUCTION}

Sexual abuse of the child is a wide-ranging problem with physical, emotional, social, moral, cultural and legal dimensions. According to the World Health Organization, child sexual abuse is the involvement of a child in sexual activity that he or she does not fully comprehend, is unable to give informed consent to, or for which the child is not developmentally prepared and cannot give consent, or that violates the laws or social taboos of the society ${ }^{(1)}$.

The Diagnostic and Statistical Manual of Mental Disorders, Fifth Edition (DSM-5) discusses the sexual abuse of the child under the subheading of "Problems related to abuse or neglect", and recommends using this category when sexual abuse of a child is the focus of clinical attention ${ }^{(2)}$.

It is difficult to reach a precise statistical data on the frequency of sexual abuse, because sexual abuse in the society is mostly hidden and not recorded ${ }^{(3)}$. It is estimated that the average worldwide prevalence of child sexual abuse is approximately $11.8 \%{ }^{(4,5)}$. In studies on child sexual abuse in our country, it was reported that this rate varied between $9.0 \%$ and $18.0 \%^{(6-8)}$. Studies reported that sexual abuse was 2-5 times more common in girls than boys ${ }^{(9-12)}$.

Child sexual abuse is considered as an important public health problem and it has negative consequences in the short and long- term. The early reactions can be fear, anxiety, avoidance, anger, inappropriate sexual words and behaviors. Especially, anxiety disorders can occur in a short time in children who are sexually abused ${ }^{(13)}$. In addition, increased curiosity to sexuality, increased frequency of masturbation or masturbation in inappropriate environments, and sexual games can be seen. In the middle and long- term, anxiety disorder symptoms such as nightmares and fears, dissociative disorders such as amnesia and trance state, major depression, post-traumatic stress disorder and sexual behavior disorders such as excessive sexual behavior may be present ${ }^{(14)}$. It was stated that individuals with a history of sexual abuse in childhood were especially at risk for post traumatic stress disorder (PTSD) compared to those who were not been abused ${ }^{(15)}$. Moreover, it was shown that women with a history of sexual abuse were more prone to display panic episodes and depressive symptoms ${ }^{(16)}$. At the same time, it was found that anxiety disorders were observed with a higher rate in those with a sexual abuse history ${ }^{(17)}$. In addition, sexual abuse may be a determinant of early substance use ${ }^{(5)}$. It was shown that the history of abuse was a risk factor, especially in terms of smoking and cannabis use, and it was a strong determinant of early onset of alcohol use (18). However, in studies conducted, it was stated that $20-50 \%$ of the cases exposed to sexual abuse did not have any psychiatric symptoms ${ }^{(19)}$. Although it was shown in studies that some children might not have a psychiatric symptom, it was found that child abuse and neglect might result in negative consequences in terms of the behavioral, social, cognitive and emotional development of the child ${ }^{(20-23)}$.

It is important to evaluate the sexually abused child in multiple dimensions. In Child Advocacy Center (CAC) established under the Ministry of Health, there are physicians, specially trained forensic interviewers, family interviewers, representatives of the Provincial General Directorate of the Ministry of Family and Social Policies, nurses and secretaries ${ }^{(24)}$. The public prosecutor starts the forensic evaluation at CACs and law inforcement officers and lawyers manage the process ${ }^{(25)}$. Although there are studies on sexual abuse in our country, studies in this field maintain their importance in terms of investigating the factors affecting the mental health of children and adolescents subjected to sexual abuse and taking precautions.

The aim of this study was to investigate the sociodemographic characteristics, psychiatric diagnoses and factors associated with psychiatric diagnoses of children and adolescents who were referred to the child and adolescent psychiatry outpatient clinic between January 2017-December 2019 for forensic evaluation because of being sexually abused. 


\section{MATERIAL and METHOD}

Ege University School of Medicine Child and Adolescent Psychiatry Forensic Committee is a multidisciplinary committee consisting of three Forensic medicine specialists, one Child and Adolescent Psychiatry specialist, and one neurologist. Psychiatric examinations of the cases, who are directed by the judicial authorities, are performed by the Child and Adolescent Psychiatry Specialist, psychiatric diagnoses are made according to DSM 5 diagnostic criteria, and their sociodemographic and clinical features are recorded in their files. After application of psychometric and projective tests by psychologists, the evaluation scales are filled, if it is necessary a family interview and school interview with the social worker is planned. After these evaluations, the case is seen in the forensic research committee on the date of appointment.

In this study, the files of 92 children and adolescents aged between 0-18 who referred to Child and Adolescent Psychiatry Forensic Policlinic between January 2017 and December 2019 for forensic evaluation due to sexual abuse were evaluated retrospectively. Ethics committee approval for this study was obtained from the Medical Research Ethics Committee of our university (Decision No: 20-7T/90, Date: 08.07.2020).

Age, gender, education level, parental information, socioeconomic level of the family, characteristics of sexual abuse and sexual abuser, whether they had a psychiatric diagnosis and the result of the report were evaluated. The socioeconomic level of the family was classified according to the income level based on the minimum wage amount of that day in our country.

The intellectual capacity of all the cases were evaluated with the Wechsler Intelligence Scale for Children-New Version (Wechsler Intelligence Scale for Children-R-WISC-R), which is a widely used intelligence test in our country, and the final diagnosis was made clinically. In addition, the results of the Beck Depression Scale in their files given during the evaluation were also recorded.

\section{Diagnostic Tools}

\section{Wechsler Intelligence Scale for Children-R (WISC-R)}

The Wechsler Intelligence Scale for Children (WISC), developed by David Wechsler in 1949, is an individually administered intelligence test for children between the ages of 6 and 16. In his study in 1974, he made some changes and carried out the standardization study on a sample of 2200 people between the ages of 6-16 ${ }^{(26)}$. Standardization of the scale on Turkish children was done by Savaşır and Şahin ${ }^{(27)}$. WISC-R consists of two parts; Verbal and Performance. While Verbal Intellectual Section has the subtests such as Information, Similarities, Arithmetic, Vocabulary, Comprehension and Digit Span; Performance Intellectual Section includes subtests such as Picture Completion, Picture Arrangement, Block Design, Object Assembly and Coding Image Editing, Pattern With Cubes, Merge Parts, Password and Labyrinth subtests. Total Intellectual Section score is obtained from the sum of Verbal Intellectual Section and Performance Intellectual Section points (26).

\section{Beck Depression Inventory (BDI)}

It is a self-assessment scale with 21 items that measures somatic, emotional, cognitive, and impulsive symptoms seen in depression. The items are evaluated on a scale ranging from 0 to 3 according to the severity of depression. It has a score range of $0-63$. The cut-off point is 17 and those who score above this score are considered at risk for clinical depression. The aim of the scale is not to diagnose depression, but to count the degree of symptoms objectively ${ }^{(28)}$. The scale has two forms. The first of these is the original form developed by Beck in 1961 (29). The second version was also developed by Beck in $1978{ }^{(30)}$. According to Hisli et al. ${ }^{(31)}$, and separate studies by Hatzenbuehler, Bryson, Golin, Byerly and Glambra on university students, the reliability coefficients of the scale were between .60 and .87, and in the separate studies by Meites, Hatzenbuehler, Glambra, Burkhart, Byerly, the validity coefficients of the scale ranged between .65 and .68. Studies 
conducted in our country have reported high values regarding the validity and reliability of the scale ${ }^{(31,32)}$. The split-half and test-retest reliability coefficients of the 61 forms of the scale were reported as .78 and .65 for university students. The same form's split-half reliability coefficient was found to be .61 for depressive patients. In Hisli's study on university students, the split-half reliability coefficient of the scale was calculated as $.74^{(31)}$.

\section{Statistical Analysis}

The statistical evaluation of the data obtained was made by using SPSS Windows 22.0 package program. Age, gender, education level, parental information, socioeconomic level of the family, characteristics of sexual abuse and sexual abuser, whether they had a psychiatric diagnosis, the result of the report were evaluated by using methods of descriptive statistical analysis, and frequency analysis. Cross tables were created for categorical data and Pearson chi-square analysis was performed. The data are summarized as numbers and percentages. A p value below 0.05 was considered statistically significant for all analyzes.

\section{RESULTS}

In our study, 78 (84.8\%) cases were female and $14(15.2 \%)$ were male. Mean age of the cases was $14.1 \pm 3.88$ years. When the educational status of the cases was evaluated, it was found that the patients were receiving preschool education $(n=2 ; 2.2 \%)$, and special education ( $n=2 ; 2.2 \%)$, while $37(40.2 \%)$ of them were primary school students, 39 (42.3\%) were high school students, and 2 (2.2\%) patients were high school graduates. Still $9(9.8 \%)$ patients dropped out of school, and 1 (1.1\%) case was illiterate. Besides, the patients were coming from families with low ( $n=55 ; 59.8 \%)$, medium $(n=32$; $34.8 \%$ ), and high ( $n=5: 5.4 \%$ ) socioeconomic status. Sociodemographic characteristics of the cases are summarized in Table 1.

The rate of smoking was $16.4 \%$ among the cases with available data in the study group $(n=67)$. Three patients (3/65) were alcohol users. Based on accessible data 6 (9.1\%) of 66 patients were substance users.

Sexual abuse was in the form of touching in 89 (96.7\%) of 92 cases, while in 40 of them $(43.5 \%)$ sexual abuse involving penetration was revealed. The most common type of sexual abuse was touching without penetration $(n=48 ; 52.2 \%)$, followed by vaginal penetration ( $n=24 ; 26.1 \%)$. Sexual abuse was commited with anal penetration in $13(14.1 \%)$, oral penetration in $3(3.3 \%)$, exhibitionism in $2(2.2 \%)$, by dragging into prostitution in $1(1.1 \%)$ and video shooting in 1 (1.1\%) case.

It was determined that coercion and physical violence were used in $63(68.5 \%)$ cases. While 48 (52.2\%) cases were exposed to sexual abuse once,

Table 1. Sociodemographic characteristics of sexual abuse victims.

\begin{tabular}{|c|c|c|c|c|c|}
\hline \multicolumn{6}{|c|}{ Sociodemographic characteristics (n, \%) } \\
\hline Gender $(n=92)$ & & & Family Status ( $\mathrm{n}=92$ ) & & \\
\hline Female & 78 & 84.8 & Together & 50 & 54.3 \\
\hline Male & 14 & 15.2 & Not Together & 42 & 45.7 \\
\hline Educational Status ( $n=92)$ & & & Who he/she lives with $(n=92)$ & & \\
\hline Illiterate & 1 & 1.1 & With mother and father & 49 & 53.3 \\
\hline Dropped out of school & 9 & 9.8 & With mother & 30 & 32.6 \\
\hline Special education & 2 & 2.2 & With father & 3 & 3.3 \\
\hline Pre-school education & 2 & 2.2 & With parent and step parent & 3 & 3.3 \\
\hline Elementary School & 37 & 40.2 & With relatives & 4 & 4.3 \\
\hline High School & 39 & 42.3 & In the institution & 2 & 2.1 \\
\hline High School Graduate & 2 & 2.2 & With spouse & 1 & 1.1 \\
\hline \multicolumn{6}{|l|}{ Socioeconomic Staus $(n=92)$} \\
\hline Low & 55 & 59.8 & & & \\
\hline Middle & 32 & 34.8 & & & \\
\hline High & 5 & 5.4 & & & \\
\hline
\end{tabular}


Table 2. Characteristics of sexual abuse.

\begin{tabular}{|c|c|c|c|c|c|}
\hline \multicolumn{6}{|l|}{ Characteristics of sexual abuse (n, \%) } \\
\hline Contact for sexual purpose $(n=92)$ & & & Number of the sexual abuser $(n=92)$ & & \\
\hline Yes & 89 & 96.7 & One & 75 & 81.5 \\
\hline No & 3 & 3.3 & More than one & 17 & 18.5 \\
\hline Penetration $(n=92)$ & & & Gender of the sexual abuser $(n=92)$ & & \\
\hline Yes & 40 & 43.5 & Female & 1 & 1.1 \\
\hline No & 52 & 56.5 & Male & 91 & 98.9 \\
\hline Use of force and physical violence $(n=92)$ & & & Sexual abuse within the family $(n=92)$ & & \\
\hline Yes & 63 & 68.5 & Yes & 32 & 34.8 \\
\hline No & 29 & 31.5 & No & 60 & 65.2 \\
\hline Number of the sexual abuse $(n=92)$ & & & Another victim or other victims $(n=92)$ & & \\
\hline Once & 48 & 52.2 & Yes & 10 & 10.9 \\
\hline More than once & 44 & 47.8 & No & 82 & 89.1 \\
\hline
\end{tabular}

Table 3. Psychiatric diagnoses of the cases.

\begin{tabular}{lcc}
\hline Psychiatric diagnoses & $\mathbf{n}$ & \%* $^{*}$ \\
\hline Post Traumatic Stress Disorder & 29 & 31.5 \\
Major Depressive Disorder & 25 & 27.2 \\
Attention Deficit and Hyperactivity Disorder & 6 & 6.5 \\
Enuresis Nocturna & 6 & 6.5 \\
Bipolar Disorder & 4 & 4.3 \\
Substance Use Disorder & 3 & 3.3 \\
Anxiety Disorder & 2 & 2.2 \\
& &
\end{tabular}

*Numbers and percentages were calculated separately for each diagnosis. and $44(47.8 \%)$ cases more than once.

It was observed that there was one abuser in 75 $(81.5 \%)$, and more than one abuser in 17 (18.5\%) cases. It was determined that the abuser was male in 91 (98.9\%) cases, and female in only 1 case. In 32 $(34.8 \%)$ cases, the abuser was within the family, and in $60(65.2 \%)$ cases the abuser was not. There were another victim or other victims in 10 (10.9\%) cases. Table 2 shows the characteristics of the sexual abuse.

Table 4. Comparison of the cases with and without a psychiatric diagnosis in terms of the characteristics of sexual abuse.

\begin{tabular}{|c|c|c|c|c|c|c|}
\hline \multirow[b]{2}{*}{ Characteristics of sexual abuse } & & \multicolumn{2}{|c|}{$\begin{array}{l}\text { With a psychiatric } \\
\text { diagnosis }\end{array}$} & \multicolumn{2}{|c|}{$\begin{array}{c}\text { Without a psychiatric } \\
\text { diagnosis }\end{array}$} & \multirow[b]{2}{*}{$\mathbf{P}$} \\
\hline & & $\mathbf{n}$ & $\%$ & $\mathbf{n}$ & $\%$ & \\
\hline \multirow[t]{2}{*}{ Contact for sexual purpose } & Yes & 48 & 53.9 & 41 & 46.1 & \multirow[t]{2}{*}{0.663} \\
\hline & No & 2 & 66.7 & 1 & 33.3 & \\
\hline \multirow[t]{2}{*}{ Penetration } & Yes & 25 & 62.5 & 15 & 37.5 & \multirow[t]{2}{*}{0.169} \\
\hline & No & 25 & 48.1 & 17 & 51.9 & \\
\hline \multirow[t]{2}{*}{ Number of the sexual abuse } & Once & 25 & 52.1 & 23 & 47.9 & \multirow[t]{2}{*}{0.649} \\
\hline & More than once & 25 & 56.8 & 19 & 43.2 & \\
\hline \multirow[t]{2}{*}{ Number of the sexual abuser } & One & 39 & 52.0 & 36 & 48.0 & \multirow[t]{2}{*}{0.342} \\
\hline & More than one & 11 & 64.7 & 6 & 35.3 & \\
\hline \multirow[t]{2}{*}{ Sexual abuse within the family } & Yes & 17 & 53.1 & 15 & 46.9 & \multirow[t]{2}{*}{0.863} \\
\hline & No & 33 & 55.0 & 27 & 45.0 & \\
\hline \multirow[t]{2}{*}{ Use of force and physical vio-lence } & Yes & 39 & 61.9 & 24 & 38.1 & \multirow[t]{2}{*}{0.032} \\
\hline & No & 11 & 37.9 & 18 & 62.1 & \\
\hline \multirow[t]{2}{*}{ Another victim or other victims } & Yes & 5 & 50.0 & 5 & 50.0 & \multirow[t]{2}{*}{0.770} \\
\hline & No & 45 & 54.9 & 37 & 45.1 & \\
\hline
\end{tabular}

A psychiatric diagnosis was found in 50 (54.3\%) participants. The most common psychiatric diagnoses were posttraumatic stress disorder $(n=29 ; 31.5 \%)$ and major depressive disorder $(n=25 ; 27.2 \%)$.
Psychiatric diagnoses are summarized in Table 3. Intellectual disability was found in $16(17.4 \%)$, and borderline intellectual functionality in 7 (7.6\%) victims of abuse. Since the diagnoses related to 
Table 5. The results of forensic reports of the cases.

\begin{tabular}{lcc}
\hline The results of forensic reports of the cases & $\mathbf{n}$ \\
\hline His/her statements can be relied on & 30 & 32.6 \\
His/her mental health is impaired & 15.2 & 14 \\
His/her statements can be relied on, but he/she does not perceive the legal meaning and consequences of the act & 10.9 \\
He/she does not perceive the legal meaning and consequences of the act & 9 & 9.8 \\
His/her mental health is not impaired & 6.5 \\
Post-observation evaluation is appropriate & 6.5 \\
His/her statements can be relied on and his/her mental health is impaired & 4.3 \\
His/her statements can not be relied on & 3.3 \\
He/she perceives the legal meaning and consequences of the act & 3.3 \\
He/she did not come to committee & 3.3 \\
His/her statements can be relied on and he/she perceives the legal meaning and consequences of the act & 2 \\
His/her statements can be relied on and his/her mental health is not impaired & 2.1 \\
His/her statements can not be relied on and he/she does not perceive the legal meaning and consequences of the act & 1 & 1.1 \\
Total & 92 & 100.0
\end{tabular}

intellectual capacity existed before sexual abuse, they were excluded from the scope of psychiatric diagnosis.

When the sexual abuse characteristics of 92 cases with and without psychiatric diagnosis were compared, the presence of a psychiatric diagnosis was found to be significantly higher in cases exposed to coercion and violence $(p=0.032)$ (Table 4). The mean BDI score was $24.86 \pm 13.28$. There was no significant difference in terms of BDI scores between the group with psychiatric diagnosis and those without $(p=0.069)$.

Various issues were inquired by the judicial authorities. They investigated whether the victims perceived the legal meaning and consequences of the act $(n=11 ; 12.0 \%)$, whether they could rely on the statements of the victims $(n=31 ; 33.7 \%)$ and whether victims had mental health impairment $(n=22 ; 23.9 \%)$. The other issues inquired by the judicial authorities were about the reliability of the child's statement, possible impairment of mental health due sexual abuse. In one case, they wanted to know whether the victim could defend himself/ herself against the sexual assault. Table 5 shows the results of forensic reports of the cases.

\section{DISCUSSION}

In our study, a psychiatric diagnosis was detected in $54.3 \%$ of the cases. The most common psychiatric diagnoses were posttraumatic stress disorder and major depressive disorder. The presence of a psychiatric diagnosis was found to be significantly higher in cases exposed to coercion and violence.

Mean age of the cases included in our study was $14.1 \pm 3.88$ years which was comparable to other studies conducted in Turkey ${ }^{(33-36)}$. In the literature, there were many studies showing that sexual abuse was seen with a higher rate in girls compared to boys $(33,34,36-38)$. In our study, $84.8 \%$ of 92 cases evaluated were female and $15.2 \%$ of them were male. The significantly greater number of female patients among sexual abuse victims was also confirmed in previous studies on this topic. It was stated that sexual abuse of boys occured, and reported less frequently than girls ${ }^{(39)}$. This situation was associated with the fact that sexually abused boys saw seeking help in this regard as an inappropriate behaviour for manhood and might be more reluctant to describe their experiences due to their thoughts of being considered homosexual ${ }^{(39)}$. Although sexual abuse cases are mostly seen in cases with a low socioeconomic level, it should not be overlooked that they are seen in all economic classes. In studies conducted in Turkey, it was reported that a significant portion of the children who were victims of sexual abuse were the children of families with low socioeconomic status ${ }^{(40,41)}$. It was observed that $59.8 \%(n=55)$ of 92 cases included in our study came from families with a low socioeconomic level. Low socioeconomic level may be an important risk factor in terms of sexual abuse as well as physical abuse 
and neglect; it was stated that this risk might be related to the problems in parental functions such as crowded family structure, decreased time allocated to the child, insufficient parental supervision, control and guidance ${ }^{(9,42,43)}$.

Studies have showed that almost all of the abusers were male ${ }^{(33,44)}$. In a study, it was found that the abuser was a familiar person in $64.4 \%(n=58)$ and a family member in $21.1 \%(n=19)(45)$ of the cases. In $34.8 \%(n=32)$ of the cases in our study, the abuser was within the family. It was thought that the reason for the higher rate of sexual abuse within the family in our study might be the result of the characterictics of forensic cases applied to our committee.

In one study it was found that sexual abuse was committed mostly by touching and handling (46.8\%) (38). In a study in which 157 children and adolescents who were sexually abused were evaluated, it was reported that $56.1 \%$ of the sexual abuse was committed by touching-caressing-rubbing followed by vaginal penetration ${ }^{(44)}$. In our study, the most common form of sexual abuse was touching with $52.2 \%(n=48)$, followed by vaginal penetration with $26.1 \%(n=24)$.

When the literature was reviewed, it was observed that repetitive attempts at sexual abuse frequently occurred ${ }^{(46)}$. In a study where 183 children and adolescents as victims of sexual abuse were evaluated, it was stated that $42.1 \%$ of the cases were abused more than once ${ }^{(47)}$.

In our study, it was found that $47.8 \%(n=44)$ of the cases were exposed to sexual abuse more than once.

It has been demonstrated that a history of sexual abuse could induce development of many psychiatric disorders in childhood and later on ${ }^{(48)}$. It was known that psychopathologic disorders were more frequently encountered in children who experienced more severe sexual trauma ${ }^{(14)}$. It was stated that psychopathology of adolescents is more frequently impaired due to their higher knowledge of sexual issues than younger children ${ }^{(49)}$. In a study conducted with approximately 43 thousand cases in the USA, it was found that suicide attempts were higher in individuals who were victims of abuse ${ }^{(50)}$. In the literature, it was stated that the family's supportive attitudes towards the child who is the victim of abuse decrease the prevalence of depression among them ${ }^{(51)}$. In our study, a psychiatric disorder was diagnosed in 50 (54.3\%) of them and the most common psychiatric diagnosis was posttraumatic stress disorder ( $n=29 ; \% 31.5)$, followed by major depressive disorder $(n=25 ; \% 27.2)$. When the sexual abuse characteristics of 92 cases with and without psychiatric diagnosis were compared, the presence of a psychiatric diagnosis was found to be significantly more frequent in cases exposed to coercion and violence. In the study of Öztürk et al., similar to our study, it was found that the rate of psychiatric diagnosis was higher in cases subjected to physical violence ${ }^{(52)}$. Children with intellectual disability are at higher risk for sexual abuse ${ }^{(46,53)}$.

In studies performed in Turkey higher rates of intellectual disability was detected in sexually abused cases, ${ }^{(54,55)}$. When the psychiatric diagnoses of 92 cases in our study were examined, it was observed that $17.4 \%(n=16)$ of the cases had intellectual disability and $7.6 \%(n=7)$ of them had borderline intellectual functioning.

It was observed that the judicial authorities inquired most frequently namely in $58(63.0 \%)$ cases, whether statements of the victims could be relied on. Deficiencies in mental capacity and deprivation of social support can prevent children from expressing themselves fully and cause an opinion that there is contradiction in expressions. In addition, children can change their expressions during the judicial process due to the fact that they can be easily influenced and exposed to pressure by adults for various economic and socio-cultural reasons. This situation may cause this problem to be brought to the agenda frequently, especially in judicial processes regarding children.

The second most frequently asked question ( $n=34 ; 37.0 \%$ ) by the judicial authorities was whether mental health of the victim was impaired. This concept, which was included in our criminal code between 2005 and 2014, was considered as an aggravating factor in punishment. This concept, which caused great controversy between lawyers 
and physicians, associations and non-governmental organizations after entering in the Turkish Criminal Code, was removed from the criminal code in 2014. Although the applications between 2017-2019 were analyzed in our study, the concept of mental health impairment was still an issue to be evaluated in previous cases. The concept of "mental health impairment", which is required to be evaluated, is legally different from the presence of a psychiatric diagnosis. In short, it is defined as a sustained psychologically traumatic condition which fully meets the diagnostic criteria of a psychiatric disease, and impairs functionality of the victim, but does not improve despite regular and adequate psychiatric follow-up and treatment, ${ }^{(56)}$. Considering these criteria, it was observed that mental health was impaired in 18, and was not in 7 cases. In 6 cases, evaluation after observation was found to be appropriate. It was seen that 3 of the 34 cases did not come to the committee. The decision that there was no impairment in mental health in 7 cases did not eliminate the existence of crime of sexual abuse and did not mean that the child was not affected by this incident. It meant that it did not exert a permanent mental adverse effect on the victim that resulted in impairment of functionality and increase in legal punishment of the abuser.

Judicial authorities also inquired whether the abused child perceived the legal meaning and consequences of the act $(n=25 ; 27.2 \%)$, whether the victim could defend himself/herself $(n=1 ; 1.1 \%)$ and whether he/she had mental illness ( $n=1 ; 1.1 \%)$. Although the punishment of sexual crimes committed against children is heavier than adults in our criminal law, these questions reveal the existence of aggravating factors in crimes committed against more risky groups among abused children.

\section{CONCLUSION}

It is very important to provide the necessary psychiatric support to the victims of sexual abuse. With the work to be done in this field, awareness can be increased and necessary precautions can be taken.
When conducting forensic-medical evaluations in cases of sexual abuse, it is important to evaluate the issues asked objectively after examining court files, and the results of the necessary psychiatric examinations, tests and family interviews. In addition, from a legal perspective, the purposes of the forensic reports written should be known and action should be taken in accordance with the legal legislation.

Ethics Committee Approval: Ege University Medical Research Ethics Committee approval was obtained (08.07.2020/20-7T/90).

Conflict of Interest: The authors declared that there were no conflict of interest.

Funding: The authors recevied no specific funding for this work.

Informed Consent: Obtained.

\section{REFERENCES}

1. https://www.who.int/violence_injury_prevention/ resources/publications/en/guidelines_chap7.pdf

2. American Psychiatric Association (APA). Diagnostic and statistical manual of mental disorders, $2013 ; 5^{\text {th }}$ ed. Arlington, VA: American Psychiatric Association.

https://doi.org/10.1176/appi.books.9780890425596

3. Theodore AD, Chang JJ, Runyan DK, Hunter WM, Bangdiwala SI, Agans R. Epidemiologic features of the physical and sexual maltreatment of children in the Carolinas. Pediatrics. 2005;115(3):e331.

https://doi.org/10.1542/peds.2004-1033

4. Stoltenborgh $\mathrm{M}$, van ljzendoorn MH, Euser EM, BakermansKranenburg MJ. A global perspective on child sexual abuse: meta-analysis of prevalence around the world. Child Maltreat. 2011;16(2):79-101.

https://doi.org/10.1177/1077559511403920. Epub 2011 Apr 21. PMID: 21511741.

5. Sanjeevi J, Houlihan D, Bergstrom KA, Langley MM, Judkins J. A Review of Child Sexual Abuse: Impact, Risk, and Resilience in the Context of Culture. J Child Sex Abus. 2018;27(6):622-41. https://doi.org/10.1080/10538712.2018.1486934. Epub 2018 Jul 31. PMID: 30064308.

6. Erdoğan A, Tufan E, Karaman MG, Atabek MS, Koparan C, Özdemir E, Baranova Çetiner A, Yurteri N, Öztürk Ü, Kurçer MA, Ankaralı H. Characteristic features of perpetrators of sexual abuse on children and adolescents in four different regions of Turkey. Anatol J Psych. 2011;12:55-61.

7. Aydin B, Akbas S, Turla A, Dundar C, Yuce M, Karabekiroglu K. Child sexual abuse in Turkey: an analysis of 1002 cases. J Forensic Sci 2015;60(1):61-5. https://doi.org/10.1111/1556-4029.12566

8. Akco S, Dagli T, Inanici MA, Kaynak H, Oral R, Sahin F, Sofuoglu Z, Ulukol B. Child abuse and neglect in Turkey: professional, governmental and non-governmental achievements in improving the national child protection 
system. Paediatr Int Child Health. 2013;33(4):301-9. https://doi.org/10.1179/2046905513Y.0000000088. Epub 2013 Sep 19. PMID: 24070409.

9. Putnam F. Ten-year research update review: child sexual abuse. J Am Acad Child Adolesc Psychiatry. 2003;42:269-78. https://doi.org/10.1097/00004583-200303000-00006

10. Finkelhor D. The international epidemiology of child sexual abuse. Child Abuse Negl. 1994;18:409-17. https://doi.org/10.1016/0145-2134(94)90026-4

11. Fiş NP, Arman A, Kalaça S, Berkem M. Psychiatric evaluation of sexual abuse cases: A clinical representative sample from Turkey. Child Youth Serv Rev. 2010;32:1285-90. https://doi.org/10.1016/j.childyouth.2010.04.020

12. Küçüker H. Analysis of 268 child and adolescent victims of sexual assault and the legal outcome. Turk J Pediatr. 2008;50:313-6.

13. Taner Y, Gökler B. Çocuk istismarı ve ihmali: psikiyatrik yönleri. Acta Medica [Internet]. 1Feb.2004 [cited 29Nov. 2020];35(2):82-6. Available from: https://actamedica.org/ index.php/actamedica/article/view/188.

14. Green AH. Factors contributing to the generational transmission of child maltreatment. J Am Acad Child Adolesc Psychiatry. 1998;37(12):1334-6. https://doi.org/10.1097/00004583-199812000-00018

15. McLean, LM, Gallop R. Implications of childhood sexual abuse for adult borderline personality disorder and complex posttraumatic stress disorder. Am J of Psychiatry. 2003;160(2):369-71. https://psycnet.apa.org/doi/10.1176/appi.ajp.160.2.369.

16. Haileye A. Psychopathological correlates of child sexual abuse: The case of female students in Jimma Zone, South West Ethiopia. Ethiop J of Health Sci. 2013;23(1):32-8.

17. Allen B, Tellez A, Wevodau A, Woods CL, Percosky A. The impact of sexual abuse committed by a child on mental health in adulthood. J of Interpers Violence. 2014;29(12):225772. https://doi.org/10.1177/0886260513517550

18. Sartor CE, Waldron M, Duncan AE, Grant JD, McCutcheon VV, Nelson EC, Heath AC. Childhood sexual abuse and early substance use in adolescent girls: The role of familial influences. Addiction. 2013;108(5):993-1000. https://doi.org/10.1111/add.12115

19. Kendall-Tackett KA, Williams LM, Finkelhor D. Impact of sexual abuse on children: a review and synthesis of recent empirical studies. Psychol Bull. 1993;113(1):164-80. Review. https://doi.org/10.1037/0033-2909.113.1.164

20. Kendall-Tackett K. The health effects of childhood abuse: four pathways by which abuse can influence health. Child Abuse Negl. 2002;26(6-7):715-29. Review. https://doi.org/10.1016/S0145-2134(02)00343-5

21. Nurcombe B. Child sexual abuse I: psychopathology. Aust $\mathrm{N}$ Z J Psychiatry. 2000;34(1):85-91. Review. https://doi.org/10.1046/j.1440-1614.2000.00642.x

22. Springer KW, Sheridan J, Kuo D, Carnes M. The long-term health outcomes of childhood abuse. An overview and a call to action. J Gen Intern Med. 2003;18(10):864-70. https://doi.org/10.1046/j.1525-1497.2003.20918.x

23. Tanner K, Turney D. What do we know about child neglect? A critical review of the literatüre and its application to social work practice. Child \& Family Social Work (internet). 2003;8(1):25-34. https://doi.org/10.1046/j.1365-2206.2003.00267.x

24. Merkezleri I, Yüksel F, Keser N, Odabaş E, Kars G, Yurtkulu F, et al. Çocuk İstismarı ve Çocuk İzlem Merkezleri. Tıbbi Sosyal
Hizmet Dergisi. 2013;(2):18-22. Retrieved from https:// dergipark.org.tr/tr/pub/tshd/issue/52278/684019.

25. Bag O, Alsen S. The evaluation of child sexual abuse in child advocacy center: one year experience of a single center]. Anatol J Psych. 2017;18(1):62-8. Turkish. https://doi.org/10.5455/apd.214951

26. Wechsler D. WISC-R Manual for the Wechsler Intelligence Scale for Children revised. 1974; New York: Psychological Corporation.

27. Savaşır I, Şahin N. Wechsler Çocuklar için Zeka Ölçeği (WISC-R) El Kitabı. Ankara. 1995; Türk Psikologlar Derneği Yayınları.

28. Savaşır I, Şahin N. Beck Depresyon Envanteri (BDE). Içinde: Savaşır I, Şahin NH, editörler. Bilişsel davranışçı terapilerde değerlendirme: sık kullanılan ölçekler. Türk Psikologlar Derneği Yayınları; 1997. s. 23-38.

29. Beck AT, Ward C., Mendelson M. Beck depression inventory (BDI). Arch Gen Psychiatry. 1961;4(6):561-71. https://doi.org/10.1001/archpsyc.1961.01710120031004

30. Beck AT, Steer RA. Internal consistencies of the original and revised beck depression inventory. J Clin Psychol. 1984;40(6):1365-7.

h t t p s: / / d o i.org/ $10.1002 / 1097$ 4679(198411)40:6<1365::AID-JCLP2270400615>3.0.CO;2-D

31. Hisli N. A reliability and validity study of Beck Depression Inventory in a university student sample. J Psychol. 1989;7(23):3-13.

32. Hisli N. A study on the validity of Beck Depression Inventory J Psychol. 1988;6:118-22.

33. Soylu N, Senturk Pilan B, Ayaz M, Sonmez S. Study of factors affecting mental health in sexually abused children and adolescent. Anatol J Psych. 2012;13:292-8.

34. Donmez YE, Soylu N, Ozcan OO, Yuksel T, Demir AC, Bayhan PC, Miniksar DY. Sociodemographic and clinical features of our sexually abused child and adolescent cases. J Turgut Ozal Med Cent. 2014;21:44-8. https://doi.org/10.7247/jtomc.2013.1170

35. Ayraler Taner H, Cetin FH, Isik Y, Iseri E. Psychopathology in abused children and adolescents and related risk factors]. Anatol J Psych. 2015;16(4):294-300. Turkish. https://doi.org/10.5455/apd.162514

36. Alşen Güney S, Bağ Ö. Protective and Supportive Injunctions for Children Exposed to Sexual Abuse: The First Data from Turkey. J Child Sex Abus. 2020;29(6):627-37. https://doi.org/10.1080/10538712.2019.1703234. Epub 2020 Feb 10. PMID: 32040385.

37. Öztop DB, Özcan ÖÖ. The Sociodemographic and Clinical Evaluation of Sexually Abused Children. New Symposium J. 2010;48:4.

38. Göker Z, Aktepe E, Hesapçığlu ST, Kandil S. Referral types of sexuallyabused children and theirclinic and sociodemographic features. SDÜ Tıp Fakültesi Derg. 2010;17(4):15-21.

39. Pereda N, Guilera G, Forns M, Gomez-Benito J. The international epidemiology of child sexual abuse: a continuation of Finkelhor. Child Abuse Negl. 2009;33:33142. https://doi.org/10.1016/j.chiabu.2008.07.007

40. Yektaş Ç, Tufan AE, Büken B, Yurteri Çetin N, Yazici M. Evaluation of abuse and abuser's features and risk factors associated with psychopathology in children and adolescents victimized by sexual abuse. Anatol J Psych. 2018;19(5):501-8. https://doi.org/10.5455/apd.291908

41. Çetin K, Altıner H. Sociodemographical Evaluation of Children 
with Sexual Abuse. Necmettin Erbakan University Ereğli Faculty of Education Journal. 2019;1(2):135-47.

42. Nelson E, Heath A, Madden P, Cooper L, Dinwiddie SH, Bucholz KK, Association between self-reported childhood sexual abuse and adverse psychosocial outcomes: results from a twin study. Arch Gen Psychiatry. 2002;59:139-46. https://doi.org/10.1001/archpsyc.59.2.139

43. Mullen P, Martin J, Anderson J, Romans S, Herbison G. Childhood sexual abuse and mental health in adult life. $\mathrm{Br} J$ Psychiatry. 1993; 163:721-32.

https://doi.org/10.1192/bjp.163.6.721

44. İmren G, Ayaz S, Yusufoğlu C, Arman A. Clinical features and risk factors related with suicide attempts in sexually abused children and adolescents. Marmara Medical J. 2013;26:11-6. https://doi.org/10.5472/MMJ.2012.02518.1

45. Gençoğlan S, Hekimoğlu Y, Mutluer T, Özdemir PG, Gümüş O, Durmaz O, Nasıroğlu S, Aşırdizer M. Sociodemographic and Clinical Characteristics of Sexually Abused Children and Adolescents Cases Living in Turkey's Eastern Anatolia Region. Van Med J. 2016;23(4):318-23. https://doi.org/10.5505/vtd.2016.46330

46. Koçak U, Alpaslan AH. Psychiatric Disorders and Sociodemographic Characteristics of Sexually Abused Children and Adolescents. Bull Leg Med. 2015;20(1):27-33. https://doi.org/10.17986/blm.2015110915

47. IşıkÜ, AktepeE, ŞïmşekF, AkyıldızA, YıldızA. Sociodemographic, Clinical and Family Characteristics of Victims of Sexual Abuse in a University Hospital in Isparta Province: 2014-2018 Data. Süleyman Demirel University Journal Of Health Sciences. 2019;10(1):53-7. https://doi.org/10.22312/sdusbed.514228

48. Hornor G. Child sexual abuse: consequences and implications. J Pediatr Health Care. 2010;24(6):358-64. https://doi.org/10.1016/j.pedhc.2009.07.003
49. Cutajar MC, Mullen PE, Ogloff JR, Thomas SD, Wells DL, Spataro J. Psychopathology in a large cohort of sexually abused children followed up to 43 years. Child Abuse Negl. 2010;34:813-22.

https://doi.org/10.1016/j.chiabu.2010.04.004

50. Harford TC,Yi HY, Grant BF. Associations between childhood abuse and interpersonal aggression and suicide attempt among US adults in a national study. Child Abuse Negl. 2014;38:1389-98. https://doi.org/10.1088/1475-7516/2014/02/011

51. Musliner KL, Singer JB. Emotional support and adult depression in survivors of childhood sexual abuse. Child Abuse Negl. 2014;38:1331-40. https://doi.org/10.1088/1475-7516/2014/01/016

52. Öztürk M, Uzel Tanrıverdi B, Yalın Sapmaz Ş. Evaluating sociodemographic and clinical properties of sexually abused children and adolescents, psychopatology and associated risk factors, Turk J Child Adolesc Ment Health. 2017;24:15563.

53. Euser S, Alink LR, Tharner A, van IJzendoorn MH, BakermansKranenburg MJ. The Prevalence of Child Sexual Abuse in Out-of-home Care: Increased Risk for Children with a Mild Intellectual Disability. J Appl Res Intellect Disabil. 2016; 29(1):83-92. https://doi.org/10.1111/jar.12160

54. Köse S, Aslan Z, Başgül ŞS. The forensic cases applied to an education and research hospital's child psychiatry department. Anatol J Psych. 2011;221-5.

55. Aksu H, Demirkaya SK, Özgür BG, Gün B. Evaluation of child and adolescent forensic cases within one year in Aydın city, in Turkey, Anatol J Psych. 2013;14(4):369-77. https://doi.org/10.5455/apd.43501

56. Kaya A, Aktas EO. The Concept of Mental Health Deterioration In The Light of The Decisions of The Higher Judicial Bodies. Turk J Med. 2013;25(2):133-9. https://doi.org/10.5080/u7495 